\title{
Investigating The Implementation Of ICT In Education Reformation: National Instructor Teachers' Perspectives
}

\author{
Thomas Wahyu Prabowo Mukti', Veronika Swanti', Mikael Dian Teguh ${ }^{3}$ \\ ${ }^{1}$ Sanata Dharma University, Indonesia \\ ${ }^{2}$ Yogyakarta Independent School, Indonesia \\ ${ }^{3}$ Alibaba UC Indonesia \\ Email authors: thomaswpm@usd.ac.id, swanti@yis-edu.org, wb-dianteguh623882@alibaba-inc.com
}

How to cite this paper:

Mukti, T. W. P., Swanti, V., \& Teguh, M. D. (2020). Investigating The Implementation of ICT In Education Reformation: National Instructor Teachers' Perspectives. International Journal of Language Teaching and Education,4(1), 13-22. https://doi.org/10.22437/ijolte.v4i1.9096

Received: April 18, 2020

Accepted: June 19, 2020

Published: July 31, 2020

This work is licensed under the Creative Commons Attribution International License (CC BY 4.0). http://creativecommons.org/licen ses/by/4.0/

(c) (i)

\begin{abstract}
To facilitate quality teachers to support individual learning and encourage students to use technology, the Indonesian Ministry of Education has launched the National Instructor Teacher Program. Although the primary objective of the program is not limited to ICT, the instructor teachers' existence is driven by the demand for technology use in classrooms. This qualitative paper aims to investigate National Instructor Teachers' perspectives toward the use of ICT in education. Data were gathered by interviewing two National Instructor teachers from two provinces, namely Jawa Tengah and Yogyakarta. The results of this study showed that National Instructor teachers had a positive attitude towards the use of ICT. They were able to share and collaborate with other teachers and could find their own solutions related to the barriers in implementing ICT in their classes. The results of this study suggest that the government take a different approach in implementing the policy and support teachers forum to encourage ICT usage in the classroom and teachers' autonomy.
\end{abstract}

\section{Subject Areas}

Educational Policy, ICT in Education

Keywords

ICT implementation, national Instructor teacher teacher's perspective

\section{Introduction}

Teachers are indispensable for their role in nurturing students' success in the scope of education and never-changing world adaption. It means that teachers are significant for education in general as they 
bring quality to students' life. However, teachers' roles are not limited to its namesake, as it will make them no more than a pawn in the ever-growing society. Ideally, teachers should be able to introduce, envision, and deliver the real world to the students (Rohwati, 2012), allowing them to embrace the idea of adapting society. In short, they should embrace integrity, optimism, and work engagement.

In order to realize the aforementioned idealism, learning is nonetheless obligatory for teachers. Therefore, the Indonesian Government has required teachers to simultaneously upgrade their knowledge and skill (Undang-Undang nomor 14 tentang Guru dan Dosen, 2005). The government has provided them with a number of programs and ongoing assessments, including Uji Kompetensi Guru (UKG/ Teachers' Competency Test). UKG is a set of tests that aims to measure teachers' competence and monitor teachers' quality. Sadly, it has been underperforming, with the latest nation-wide UKG outcome in 2015 rated 56.69 out of 100 - a far cry from ideal (Ditjen Guru dan Tenaga Kependidikan, 2016, p. 9). Indeed, the quality remains an unresolved problem for education in Indonesia.

Therefore, as an effort to provide solutions to the existing quality issue, the government has launched the National Instructor Teacher (Ditjen Guru dan Tenaga Kependidikan, 2016, p. 10). The program takes quality-rated teachers to assist their under-par colleagues in achieving a certain standard of teaching practice. Moreover, the program also employs public participation, in the likes of the regional government, professional association, university, business, and industrial sector, non-government organization, and parents. The government expects that the breakthrough program and public participation can improve education quality in general.

The problem in improving education quality in modern days is the fact that digitalization has taken place, occupying all sectors. It means that increasing quality in teaching practice must come hand-in-hand with improving Information and Communication Technology (ICT) implementation. ICT offers massive exploration to the sphere of teaching and learning activities, breaking the classic interface with a new borderless possibility. Undeniably, it helps teachers improve their performance, which leads to a better education quality (Sumintono et al., 2012) but also bigger challenges.

In this sense, teachers have an important role in the integration of information and communication technology (ICT) in education because teachers are the key component for learning using ICT in schools (Cahyani \& Cahyono, 2012; Hermawan et al., 2018; Hu \& McGrath, 2012; Marwan \& Sweeney, 2010; Prestridge, 2012; Rohwati, 2012; Sumintono et al., 2012). However, ICT implementation in Indonesia is often hampered by the fact that there are no supporting infrastructure, not enough time, and limited resources and the government policy of removing ICT subject from the curriculum in (Hermawan et al., 2018). It may lead teachers to the conclusion that ICT may not be that significant in their classes. It can be seen from the finding that some teachers are still reluctant to implement ICT in their class (Harendita, 2013 ) including the finding that $87 \%$ of teachers (English teachers in this study) were still in beginner level based on UNESCO ICT teacher competency framework (Dwiono et al., 2018). The fact above can explain how difficult it is to implement ICT in education.

This is where the National Instructor teachers are advised to step in. National Instructor teachers, generally believed to be ideal teachers due to their teaching practice mastery, should embody the mission to integrate ICT in education - especially because they are far better equipped in terms of skills and facility (Ditjen Guru dan Tenaga Kependidikan, 2016). They must be the front of ICT-motored education and be exemplary teachers for their colleagues - as their mission states. 
Thus, it can be concluded that the lingering problem is not on the supporting facility, allotted time, or resources - but on the teachers' attitude toward ICT practice. This study is expected to provide ideal insights on how teachers implement ICT in the classroom and find their perspective based on how they implement ICT inside and outside the classrooms. This study could offer a different perspective on how ICT was implemented from the perspective of National Instructor Teachers who are supposed to be pioneers and the first ones to be exposed with technology and pedagogical knowledge and later share the experiences to other teachers and train teachers who need help. Therefore, readers could gain insight on of how government programs are conducted in the field and what obstacles that might not be considered before implementing the policy.

\section{Method}

This paper is concerned with examining national instructor teachers' perspectives on ICT in education to gain a conceptual understanding of the current state of ICT implementation in the Indonesian context. A qualitative method especially using interview guidelines was employed to gather the data from two National Instructor teachers. This way, the researchers will be able to understand their perspective towards the implementation of ICT in education. The first participant is a state junior high school teacher and she is teaching Biology. She taught in Central Java. The first participant is coded as "Ani". The second participant is a private elementary school teacher teaching in Yogyakarta. The second participant is coded as "Nita".

The researchers conducted interviews with the participants more than once, either in a face-to-face setting or telephone call and limited and non-formal observation to see how the participants perceive ICT for teaching. Personal contact in the personal interview increases the likelihood that the individual will participate and provide the desired information (Ary et al., 2010). The interviews were then recorded and transcribed. The transcripts were divided into two transcripts based on the participants and the researchers sent the transcript to participants to check if there was anything to confirm or check and as respondent validation. Each researcher then analyzed the scripts using content analysis and made concise summaries of key results systematically to form themes (Erlingsson \& Brysiewicz, 2017). After that, researchers gathered all analysis and discussed the results of each researcher for the member checking phase. The researchers checked again the data analysis therefore all members contributed to the data analysis and the knowledge construction. This phase helped researchers to make sure there was no subjectivity and the data analysis were valid (Simpson \& Quigley, 2016). In addition, to get a deeper picture, researchers triangulate data with the observation.

\section{Findings and Discussion}

In this section, the researchers would like to elaborate on how National Instructor teachers deal with the implementation of Information and Communication Technology (ICT) in education.

\subsection{The National Instructor Teachers' Perspectives on the Benefits of ICT}

Teachers' perspective on the use of ICT holds a very important key to the success of ICT implementation both in the class or on the school as the whole system (Ertmer et al., 2012; Fu, 2013; Jimoyiannis \& Komis, 2007; Prestridge, 2012). Fu (2013) states that ICT in education covers the assistance for students to access 
information at ease, the support for "critical thinking development, the improvement of teaching and learning, and the support for material access" (p. 115). Based on the interview, both Ani and Nita believed that ICT was very important in their class. Ani stated,

ICT is very important. Apart from the internet, we sometimes also need information from television. For example, information about natural events or phenomena. Maybe radio is also important for students because students also need to keep up to date. ... for example, it is about photosynthesis or experiments do directly. We can use learning media. So, students can learn through that we cannot visualization and audio.

Nita also mentioned,

In my opinion, technology can help class learning: the use of the internet, the use of radio may be very helpful in learning so students can see what they are learning through the help of ICT.

Both national instructors agreed on the importance of ICT and they did not limit themselves on the use of the internet but all possible ICT like TV or radio: both of them still employed the "old model" media. Ani even underlined that television and radio were still needed to find information related to students' lives. Nita stated that television, radio, and printed media were still relevant to be used in facilitating students learning. In addition, Nita, in the interview, suggested that technology did not only cover computerized programs but it included other media used in classrooms such as laboratory apparatus for science studies. Both of them also emphasized the benefit of ICT especially for giving students visual aid which is very important for students' understanding (Anwariningsih \& Ernawati, 2013). Other than that, Nita also added that technology, especially the internet, was very useful for teachers as it enabled them to access materials suitable for teaching. The Internet had become their daily resource for classroom teaching materials. Nita explained that most teachers at school could easily type on the keywords on the search menu and sort out the suggested links to worksheet or handout providers. Ani also underlined the importance of ICT. She stated:

ICT is very helpful for teachers because without ICT we will be left behind from the developed countries.

Through the statements above, Ani emphasized how important the use of ICT in education was. She understood that teachers need to use the latest technologies in the classroom setting as one of the means in order to catch up with other countries.

Teachers' attitude, in this case, National Instructors' attitude, becomes the concern since applying ICT in the class may still become a challenge for most teachers since they have their own beliefs related to the implementation of ICT as they are expected to use media for teaching students: are they really willing to apply it in the class? The belief can intersect the pedagogical belief they have already had which creates two possibilities: a 'collision' or 'collusion'. Both of the possibilities bring their own implications on how ICT is used in the classroom (Prestridge, 2012). However, they are still expected to apply, give example, and share the use of ICT and its methodology in the class.

Teachers' explanations showed that both of them had a positive attitude towards the use of ICT in the classroom especially related to the sources from the internet. It may be also as the result of the National Instructor requirement: having basic ICT skills (word processor/data processor, data processor/ 
spreadsheet, presentation/PowerPoint, internet use - email, browsing, downloading and uploading data) (Direktorat Jenderal Guru dan Tenaga Kependidikan, 2017). In addition, the government also facilitates those teachers to join seminars and workshops related to ICT. These factors may become one of the contributing factors for teachers to form their positive attitude towards the implementation of ICT in the classroom. This positive attitude is very important since they were expected to walk the talk and become the motor of this movement.

\subsection{The Collaboration on the Use of ICT}

The fact that both National Instructor teachers have a positive attitude towards the use of ICT in the classroom enables them to the further use of ICT: collaboration both with students and their colleagues to make use of ICT in an optimum way. One of the possibilities of ICT usage in the classroom is encouraging inclusion and reflect cultural diversity on the students which depends on how teachers use it (Kastuhandani, 2016). In the other hand, National Instructor teachers are expected to be the source of information for other teachers and they should share what they have got to other teachers in MGMP (Subject Matter Teacher Association) Forum (Ditjen Guru dan Tenaga Kependidikan, 2016) although it is limiting them from getting ideas or knowledge from other teachers. It is promising since the use of ICT can help teachers share effective technology practices and experiences (Fu, 2013).

In the interview, Ani mentioned that she followed many seminars and workshops both in the regional or national scope related to the use of ICT in the classroom. Further, she also mentioned that she has a responsibility to share what she learned from those seminars and workshops in MGMP Forum to other teachers not only in her school. In addition, she also said that all of the teachers in the same subject needed to share whatever they got and their teaching experiences with other teachers in MGMP. Thus, there would be no gap between one class to another class and bring possibilities for teachers to collaborate. Nita elaborated Ani's explanation by saying that teachers could collaborate in utilizing the ICT by sharing links to useful websites and might suggest material resources for teaching to other teachers. Here is the role of the national instructor teachers: they need to master the ICT so they can share it with other teachers. It means that they are the agent of the collaboration.

In addition, the collaboration between teachers was also done through the use of Report Application for 2013 Curriculum based on Microsoft Excel®, a new method of making report cards online. Ani mentioned that she needed to share how to use and input data for other teachers. She stated,

..for teachers who have not mastered the IT technology, I or someone else may guide and share their experiences. In this term, there will be no one who left behind but we at least try to finish the online report card.

As the National Instructor, they realized that they needed to also share the use of ICTs in the classroom and guide other teachers to support the school operations based on ICT since it is very hard for other teachers to master the program. It also shows that both instructional teachers encouraged other teachers to use ICT. This way, the sharing, and collaboration may carry a higher possibility for other teachers to implement ICTs in the classes since it may promote some important aspects such as teachers' confidence, learning, reflection, and moral support (Johnson, 2003). However, if the ICT resources are insufficient or even inaccessible especially for teachers to practice skills and increase familiarity with ICT, the benefits for teachers' professional development will be only short-term (Eyles, 2018). Therefore, the government should address this problem especially for those who are not yet able to access and implement ICTs in their class. 


\subsection{The Support of the Use of ICT in the School Context}

The use of ICTs also needs supports from other components in and outside the school context. The school management, government, and private sectors can contribute to the use of ICT in the class. In this study, both Ani and Nita felt being supported by the school and the government. They mentioned,

The school is very supportive because the principal is technology literate. So, whatever we ask, if the school is able to buy, it will be granted. For example, we have had a projector in all classes. Then, if the internet bandwidth is still not enough, the school will add it. (Ani)

Schools are quite supportive with the use of today's technology by projector, viewers, internet in each class. However, computers and printers are not yet available in each class. (Nita).

In addition, Ani and Nita also told the support from the government,

The Magelang government itself is VERY supportive. So, each sub rayon is taken one. The condition is that one of them is for the highest National Examination academic scores in Sub Rayon...It is only for Sekolah Unggul (Exemplary Schools based on the government data)... Funding for each school seems like if I am not mistaken 500 million but the one managing (the budgetary) is not a school but the department is cooperating with Central Java Educational Quality Assurance Agency... (Ani)

In my opinion, the government is quite supportive of the use of today's technology, but it needs to be improved. For example, there is training or workshop of the use of renewable technology, how to access learning material that is fast, valid and easy for teachers, etc. (Nita)

Based on Ani's explanation, she felt that the school supported her effort in implementing ICTs in her classes. She gave some examples of how the school is supportive although she actually still found some problems. On the other hand, Nita highlighted the school support especially in terms of the facility provided for her and other teachers. In addition, government support was also quite adequate based on Ani's explanation. They have allocated the budget for ICT needs in each school. However, from Ani's explanation, it can be inferred that the budget was still centralized in the Central Java Educational Quality Assurance Agency and it was only for exemplary schools, not yet for all schools.

The government actually had also provided training for some teachers related to the implementation of updated technology and how to access valid learning resources easily and quickly. However, it seems that not every teacher got the chance or information or they were not willing to do so. Infrastructure might also become one of the problems. The support is not yet even and it seems that the government still focused on the exemplary schools as the pioneers; not yet all schools.

This condition also shows that the centralization policy needs to be revisited by looking at what happens on the grassroots. It seems that the government has not done the research on the schools' systems and the environment through fully that the support given is still considered not yet adequate. This topdown approach is problematic since we can still find the lack of sufficient ICT resources for teachers and students, limited ICT skills of both teachers and students and limited training opportunities for teachers (Hu \& McGrath, 2012) as we can see in this study. Ani comparison to this is the studies that show countries like Saudi Arabia, India, and Uganda uses similar approach (Albugami \& Ahmed, 2015) and it leads to the situation where ICT is not fully utilized and teachers become more reluctant since the condition does not meet., Therefore, the government needs to be aware of the complexity of the implementation and 
understand the fact that this process is indeed "fluid, non-linear, reiterative process" (Younie, 2006, p. 399).

\subsection{The Barriers in Using ICTs in the School Context}

Both National Instructor teachers believed that the use of ICT was indispensable for this moment however, they still found some barriers in implementing the ICT in their classroom. The barriers and solutions the National Instructor teachers are as follows,

First, they underlined the technical problems regarding the implementation of ICTs in the classroom. Ani mentioned,

... unstable network. So, we need to be patient. Therefore, a teacher must not depend on ICT but must also look for alternatives, (especially) if the internet is not connected because that happens often. Not only that but sometimes the laptop also cannot connect to the LCD and sometimes there is no operator. So, the teacher must cancel plan 1 and replace it with plan 2 both with the learning model for example discovery learning and then the method of discussion, then the students to present (their findings).

Nita also shared almost similar experiences:

Difficulties that I have encountered in using technology are internet network sometimes has errors, limited speakers, power outages, and so on.

Both Ani and Nita emphasized that internet connection was still the problem. In addition, the problem was also related to the hardware used to support their teaching. Ani realized that she should not depend on the internet connection or bandwidth. She believed that teachers should always prepare some alternatives for teaching. However, she still hoped that the government provides a better internet connection. Thus, teachers and students will retrieve information faster and easier. It means that the problem related to the infrastructure is not yet solved since 2004 as mentioned by Yuhetty who mentioned that ICT is the poor condition of the infrastructure, in terms of quantity and also quality (Yuhetty, 2004).

Second, not all teachers could implement ICT, even use it. Some teachers are not able to use ICTs because they are not used to it. Most teachers currently teaching are Digital immigrants who are not yet fully able to understand how to operate things in this all-internet era. It confirms Dwiono, Rochsantiningsih, and Suparno's study (2018) that show teachers can only use the basic function in a limited number of computer applications. In addition, they also still need to understand how the digital natives, their students, fit the ICT in their lives (Wulandari \& Pasaribu, 2020) so they can utilize the ICT for students' needs.

However, although there were still some problems related to the implementation, both the government and the participants actually also offered some solutions to these problems:

... for teachers who are less IT literate, I try to guide them using the application and share some information. Usually, the representatives chosen by the department, our Follow-up Plan are then told to socialize to the sub rayon level so that knowledge is not only for one teacher but also useful for other teachers. What we usually do is a collaboration with teachers who are in one subject. We have Subject Matter Teacher Association (MGMP). For example, Pak X will get X learning application, so all teachers must have it. So that all students have equitable knowledge. 
The information above shows that teachers still have positive attitudes related to the condition and they know that they need to share what they got from the government workshop or seminar with other teachers. However, some teachers still could not utilize ICT in their school since the school's budget was not sufficient. Ani previously mentioned that the government provided some big amounts of money for the development of ICT in the school however it was not yet evenly distributed. Infrastructure for ICT implementation was not a big problem for the exemplary schools which normally have a big budget from the government. However, some state and private schools did not have that budget to equip the school with ICT. It is a problem but it could not be denied that the teachers' support, in the form of teacher forums, helps the teachers to get insights on how ICT could be implemented in their schools. Although some teachers may not yet be able to implement the technology in the class, at least they have the knowledge related to how to use them and relevant information on the usage of ICTs and it may give teachers hope that later on, they can use the ICTs in their own class.

Third, inappropriate content on the internet that may affect students' mental was somehow out of teachers' control. Ani happened to find a student who accessed some pornography contents on the internet instead of finding information. She also said that when the school did some inspections, they found that some students had a lot of pornographic pictures on their phones. Thus, she realized that teachers need to control and monitor the students. Although the school had already had the operator, they still needed to control the information that students got from the internet. In this case, the government is the fittest party to control.

\section{Conclusion and Suggestion}

The two National Instructor teachers believed that the use of ICT in education was indispensable. ICT can provide a lot of alternatives and help teachers provide better information and understanding. ICT also improves students' engagement as they get more interested in learning using audio-visual media. They also believe that by implementing ICT, Indonesia will be able to catch up with other developed countries.

However, there were some problems related to the implementation of ICTs in education. They were the technical problems, the inadequate infrastructure and resources, and their control to the students' internet access. The technical problems were related to the electricity and sometimes the ICT tools did not work while a more serious issue in the inadequate infrastructure and resources was related to the lack of schools facility that can support current methods offered using ICT like no LCD projector, slow internet connection, and no reliable sources for teaching. The teacher control was still one of the problems, especially the control on what websites students can access.

The results of this study show technology implementation in National Instructor Teachers who were supposed to be the pioneers of government programs classrooms. It gave us pictures on how Indonesian teachers were still struggling to migrate from traditional learning to the learning needed in this era. It turned out the facility was still the main problem and not all schools had the same chance as other schools so that it was very difficult for National Instructor Teachers to train other teachers. This research may also become the preliminary data for researchers who wanted to compare how technology was perceived and integrated in the classroom from time to time.

Therefore, based on the findings, the researchers believe that the government and other components should provide more supports for the implementation of ICT in the school. The government needs to 
provide better facilities and resources not only in urban areas but also in rural and isolated areas around Indonesia. In addition, training on the use of technology or gadgets and how to incorporate technology, especially the current ones, for students' needs very vital. Even when teachers are able to use the ICT in the class, they may not meet students' needs due to the lack of understanding of how things are done differently both by the teachers as digital immigrants and students as digital natives. This lack of understanding can cause friction (Wulandari \& Pasaribu, 2020). It is suggested that teachers themselves need to individually improve their knowledge and skills in the use of ICT in the classroom or being more autonomous. Teachers are also required to be able to manage the information from the internet and learn their students' characteristics so that they can meet students' needs and, in the end, help them to be more autonomous (Ardi, 2017; Pasaribu, 2020).

Due to the limitation of this research underlying the implementation of ICTs in Education through National Instructor Teachers' perspectives, future researchers are suggested to conduct research focusing on the whole school teachers' perspectives, the students' perspectives, or the government's perspectives. It is also suggested to conduct research evaluating the use of ICTs at school related to other aspects of education including students' self-regulated learning, teachers' or students' motivation, students' performance, or teachers' collaboration.

\section{Acknowledgments}

We would like to thank the National Instructor teachers who were willing to spend their time on this study and appreciate their willingness to keep learning and using ICT in their class and to the editor for the constructive feedbacks.

\section{References}

Albugami, S., \& Ahmed, V. (2015). Success factors for ICT implementation in Saudi secondary schools: From the perspective of ICT directors, head teachers, teachers and students. International Journal of Education and Development Using Information and Communication Technology, 11(1), 36-54.

Anwariningsih, S. H., \& Ernawati, S. (2013). Development of interactive media for ICT Learning at elementary school based on student self learning. Journal of Education and Learning (EduLearn), 7(2), 121. https://doi.org/10.11591/edulearn.v7i2.226

Ardi, P. (2017). Promoting learner autonomy through schoology m-learning platform in an EAP class at an Indonesian university. Teaching English with Technology, 17(2), 55-76. http://www.tewtjournal.org

Ary, D., Jacobs, L., Sorensen, C., \& Razavieh, A. (2010). Introduction to research in education (8th ed.). Wadsworth CENGAGE Learning.

Cahyani, H., \& Cahyono, B. Y. (2012). Teachers' attitudes and technology use in Indonesian EFL classrooms. TEFLIN Journal, 23(2), 130-148. https://doi.org/10.15639/teflinjournal.v23i2/130-148

Dwiono, R., Rochsantiningsih, D., \& Suparno, S. (2018). Investigating the integration level of Information and Communication Technology (ICT) in the English Language Teaching. International Journal of Language Teaching and Education, 2(3), 259-274. https://doi.org/10.22437/ijolte.v2i3.5752

Erlingsson, C., \& Brysiewicz, P. (2017). A hands-on guide to doing content analysis. African Journal of Emergency Medicine, 7(3), 93-99. https://doi.org/10.1016/j.afjem.2017.08.001

Ertmer, P. A., Ottenbreit-Leftwich, A. T., Sadik, O., Sendurur, E., \& Sendurur, P. (2012). Teacher beliefs and technology integration practices: A critical relationship. Computers E Education, 59(2), 423-435. 
https://doi.org/10.1016/j.compedu.2012.02.001

Eyles, A. M. (2018). Teachers' perspectives about implementing ICT in music education. Australian Journal of Teacher Education, 43(5). https://doi.org/10.14221/ajte.2018v43n5.8

$\mathrm{Fu}$, J. S. (2013). ICT in education: A critical literature review and its implications. International Journal of Education and Development Using Information and Communication Technology, 9(1), 112-125.

Harendita, M. E. (2013). Why resist? A closer look at Indonesian teachers' resistance to ICT. International Journal of Indonesian Studies, 1(2), 79-109.

Hermawan, H. D., Deswila, N., \& Yunita, D. N. (2018). Implementation of ICT in Education in Indonesia during 2004-2017. Proceedings - 2018 International Symposium on Educational Technology, ISET 2018, 2004, 108-112. https://doi.org/10.1109/ISET.2018.00032

Hu, Z., \& McGrath, I. (2012). Integrating ICT into College English: An implementation study of a national reform. Education and Information Technologies, 17(2), 147-165. https://doi.org/10.1007/s10639-0119153-0

Jimoyiannis, A., \& Komis, V. (2007). Examining teachers' beliefs about ICT in education: Implications of a teacher preparation programme. Teacher Development, 11(2), 149-173. https://doi.org/10.1080/13664530701414779

Johnson, B. (2003). Teacher Collaboration: Good for some, not so good for others. Educational Studies, 29(4), 337-350. https://doi.org/10.1080/0305569032000159651

Kastuhandani, F. C. (2016). Technology and Young Learners. LLT Journal: A Journal on Language and Language Teaching, 17(1), 1-8. ???

Marwan, A., \& Sweeney, T. (2010). Teachers' perceptions of educational technology integration in an Indonesian polytechnic. Asia Pacific Journal of Education, 30(4), 463-476. https://doi.org/10.1080/02188791.2010.519554

Pasaribu, T. A. (2020). Challenging EFL students to read: Digital reader response tasks to foster learner autonomy. Teaching English with Technology, 20(2), 21-41.

Prestridge, S. (2012). The beliefs behind the teacher that influences their ICT practices. Computers and Education, 58(1), 449-458. https://doi.org/10.1016/j.compedu.2011.08.028

Simpson, A., \& Quigley, C. F. (2016). Member checking process with adolescent students: Not just reading a transcript. Qualitative Report, 21(2), 376-392. http://nsuworks.nova.edu/tqr

Wulandari, M., \& Pasaribu, T. A. (2020). Technology for English language learning (I). Sanata Dharma University Press.

Younie, S. (2006). Implementing government policy on ICT in education: Lessons learnt. Education and Information Technologies, 11(3-4), 385-400. https://doi.org/10.1007/s10639-006-9017-1

Yuhetty, H. (2004). ICT and Education in Indonesia. Proceedings Asia and the Pacific Seminar, 50. http://unpan1.un.org/intradoc/groups/public/documents/apcity/unpan011286.pdf 